\title{
Oxidation Resistance and Strength Retention of Silicon Nitride Coated with Lutetium Disilicate
}

\author{
Tomohiro SUETSUNA, ${ }^{\dagger}$ Masato ISHIZAKI, Motohide ANDO, Naoki KONDO,* \\ Tatsuki OHJI* and Shuzo KANZAKI* \\ Synergy Ceramics Laboratory, Fine Ceramics Research Association, 2268-1, Shimo-shidami, Moriyama-ku, Nagoya-shi $463-8687$ \\ *Synergy Materials Research Center, National Institute of Advanced Industrial Science and Technology, \\ 2268-1, Shimo-shidami, Moriyama-ku, Nagoya-shi 463-8687
}

\author{
$\mathrm{Lu}_{2} \mathrm{Si}_{2} \mathrm{O}_{7}$ コートした窒化ケイ素の耐酸化性及び強度保持性 \\ 末綱倫浩 ${ }^{\dagger}$. 石崎雅人 · 安藤元英 · 近藤直樹* · 大司達樹* · 神崎修三* \\ ファインセラミックス技術研究組合シナジーセラミックス研究所, 463-8687 名古屋市守山区下志段味字穴ヶ洞 2268-1 \\ *産業技術総合研究所シナジーマテリアル研究センター，463-8687 名古屋市守山区下志段味字穴ヶ洞 2268-1
}

\begin{abstract}
Silicon nitride $\left(\mathrm{Si}_{3} \mathrm{~N}_{4}\right)$ coated with lutetium disilicate $\left(\mathrm{Lu}_{2} \mathrm{Si}_{2} \mathrm{O}_{7}\right)$ layer through the intermediate silica $\left(\mathrm{SiO}_{2}\right)$ rich phase was fabricated by reaction sintering after dip-coating. The $\mathrm{Lu}_{2} \mathrm{Si}_{2} \mathrm{O}_{7}$ layer with a thickness of 3-29 $\mu \mathrm{m}$ was formed on $\mathrm{Si}_{3} \mathrm{~N}_{4}$ substrate. It was relatively dense with several pores, and strongly jointed to the substrate through the intermediate phase. Oxidation resistance and strength retention of the coated $\mathrm{Si}_{3} \mathrm{~N}_{4}$ were investigated and compared with those of the uncoated $\mathrm{Si}_{3} \mathrm{~N}_{4}$. Apparent activation energy for oxidation at $1300-1500^{\circ} \mathrm{C}$ in air increased up to $523.1 \mathrm{~kJ} / \mathrm{mol}$ with increasing thickness of the coating layer, which was about 1.7 times higher than that of the uncoated $\mathrm{Si}_{3} \mathrm{~N}_{4}(310.3 \mathrm{~kJ} / \mathrm{mol})$. After long-term cycling oxidation at $1500^{\circ} \mathrm{C}$ for up to $1000 \mathrm{~h}$ in air, the total weight gain decreased by up to $51 \%$, indicating that oxidation resistance improved by about $100 \%$. The improvement was attributed to the protection of the substrate from an oxidative environment by the $\mathrm{Lu}_{2} \mathrm{Si}_{2} \mathrm{O}_{7}$ layer and underlying $\mathrm{SiO}_{2}$-rich phase. Flexural strength of the coated $\mathrm{Si}_{3} \mathrm{~N}_{4}$ was not deteriorated before and after the cycling oxidation at $1500^{\circ} \mathrm{C}$ for up to $1000 \mathrm{~h}$ in comparison with that of the uncoated $\mathrm{Si}_{3} \mathrm{~N}_{4}$. However, the high-temperature strength at $1400-1500^{\circ} \mathrm{C}$ in air was a little less than that of the uncoated $\mathrm{Si}_{3} \mathrm{~N}_{4}$. The deterioration was attributed to the softening of amorphous $\mathrm{SiO}_{2}$ phase, which existed in the intermediate phase (between the $\mathrm{Lu}_{2} \mathrm{Si}_{2} \mathrm{O}_{7}$ layer and substrate) and inside the substrate.
\end{abstract}

[Received March 3, 2004; Accepted April 27, 2004]

Key-words : Lutetium disilicate, Silicon nitride, Dip-coating, Reaction sintering, Oxidation resistance, Strength retention

1. Introduction

$\mathrm{Si}_{3} \mathrm{~N}_{4}$ has excellent thermomechanical properties: high strength at elevated temperatures, low thermal expansion coefficient, and high thermal shock resistance. ${ }^{1-6)}$ Therefore it has a potential to replace conventional super alloy materials, which are currently used for high-temperature structural applications such as stator, rotor and combustor of gas turbine. To use it at higher temperatures $\left(\sim 1500^{\circ} \mathrm{C}\right)$ without cooling air as a component of gas turbine would increase thermal efficiency with a simultaneous decrease of emission of $\mathrm{CO}_{2}$ and $\mathrm{NO}_{x}$. Great efforts have been made to achieve this goal, and the mechanical properties have been improved remarkably. For example, $\mathrm{Si}_{3} \mathrm{~N}_{4}$ doped with $\mathrm{Lu}_{2} \mathrm{O}_{3}$ system as additives, such as SN 281 and SN 282 (Kyocera Corp.), has achieved higher creep resistance ${ }^{7), 8)}$ and higher strength at elevated temperatures ${ }^{9)}$ than $\mathrm{Si}_{3} \mathrm{~N}_{4}$ using other additives and provided comparable fracture toughness. ${ }^{10)}$ These excellent mechanical properties are attributed to $\mathrm{Lu}_{2} \mathrm{SiO}_{5}, \mathrm{Lu}_{2} \mathrm{Si}_{2} \mathrm{O}_{7}$ and $\mathrm{Lu}_{4} \mathrm{Si}_{2} \mathrm{O}_{7} \mathrm{~N}_{2}$ phases with high melting points in the grain boundary regions. ${ }^{7)-11)}$

\footnotetext{
† Now with Corporate Research \& Development Center, Toshiba Corporation, 1, Komukai Toshiba-cho, Saiwai-ku, Kawasaki-shi, Kanagawa 212-8582

現在 : (株) 東芝研究開発センター, 212-8582 神奈川県川崎市幸 区小向東芝町 1
}

However, one problem of $\mathrm{Si}_{3} \mathrm{~N}_{4}$ is relatively low oxidation resistance at elevated temperatures. ${ }^{12}$ This low oxidation resistance is related to the grain boundary phases, which are produced from additives of $\mathrm{Si}_{3} \mathrm{~N}_{4}$. Intrinsically, $\mathrm{Si}_{3} \mathrm{~N}_{4}$ is difficult to sinter due to the low self-diffusivity, and additives such as $\mathrm{Y}_{2} \mathrm{O}_{3}, \mathrm{Al}_{2} \mathrm{O}_{3}, \mathrm{MgO}$, and $\mathrm{Yb}_{2} \mathrm{O}_{3}$ are used to promote the densification through the liquid-phase sintering. ${ }^{1,4), 13)}$ These additives react with $\mathrm{Si}_{3} \mathrm{~N}_{4}$ and $\mathrm{SiO}_{2}$ (formed by oxidation of $\mathrm{Si}_{3} \mathrm{~N}_{4}$ ), forming amorphous and crystalline phases in the grain boundary regions during the densification. The amorphous phases accelerate the oxidation of $\mathrm{Si}_{3} \mathrm{~N}_{4}$ by the migration of additive cations. ${ }^{14)}$ When the oxidation progresses, $\mathrm{Si}_{3} \mathrm{~N}_{4}$ is damaged beneath the $\mathrm{SiO}_{2}$ scale (produced by oxidation of $\mathrm{Si}_{3} \mathrm{~N}_{4}$ ) with several pores, leading to the deterioration of mechanical properties. ${ }^{15), 16)}$ Therefore, it is necessary to prevent the oxidation of $\mathrm{Si}_{3} \mathrm{~N}_{4}$. Recently the oxidation resistance has been improved by crystallizing the grain boundary phases, ${ }^{14)}$ by using additives with small cationic radius and high melting point in the system of $\mathrm{SiO}_{2}-\mathrm{RE}_{2} \mathrm{O}_{3}$ ( $\mathrm{RE}$ : rare earth cation) ${ }^{17)}$ and by using nanoparticles such as $\mathrm{SiC}$ and $\mathrm{MoSi}_{2}$ in the grain boundary regions. ${ }^{18)-20)}$ However, these improvements are insufficient for practical use in severe environments, and it is necessary to further improve the oxidation resistance.

In the present research, $\mathrm{Si}_{3} \mathrm{~N}_{4}$ was coated with $\mathrm{Lu}_{2} \mathrm{Si}_{2} \mathrm{O}_{7}$ layer through the intermediate $\mathrm{SiO}_{2}$-rich phase. $\mathrm{Lu}_{2} \mathrm{Si}_{2} \mathrm{O}_{7}$ 
has extremely high chemical stability at high temperatures and a thermal expansion coefficient close to that of $\mathrm{Si}_{3} \mathrm{~N}_{4}{ }^{21}{ }^{21}$ The coated $\mathrm{Si}_{3} \mathrm{~N}_{4}$ was fabricated by reaction sintering after dip-coating. This coating process is simple, easy, cost-effective, and applicable even to complex-shaped components. Therefore it is much more suitable for industrial applications than are other processes such as chemical vapor deposition, spray coating, sputtering and hot-pressing. Three kinds of coated specimens were prepared to examine the oxidation resistance: single-, triple-, and 5-times-coated ones. Apparent activation energy for oxidation was examined at $1300-1500^{\circ} \mathrm{C}$ in air. Long-term cycling oxidation behavior was investigated at $1500^{\circ} \mathrm{C}$ for up to $1000 \mathrm{~h}$ in air. The flexural strength after the long-term cycling oxidation was examined, and so was high-temperature strength.

\subsection{Materials}

\section{Experimental procedure}

The raw materials used for the present research were $\alpha$-rich $\mathrm{Si}_{3} \mathrm{~N}_{4}$ (SN-E10, UBE Industries, Ltd.; >99.5\% purity), $\mathrm{Lu}_{2} \mathrm{O}_{3}$ (Shin-Etsu Chemical Co., Ltd.; $99.9 \%$ purity), and $\mathrm{SiO}_{2}$ (quartz, Kojundo Chemical Laboratory Co., Ltd.; 99.9\% purity, $0.8 \mu \mathrm{m}$ particle size) powders. $\mathrm{Si}_{3} \mathrm{~N}_{4}$ was mixed with 8 mass $\%$ of $\mathrm{Lu}_{2} \mathrm{O}_{3}$ and 2 mass $\%$ of $\mathrm{SiO}_{2}$ in ethanol for $48 \mathrm{~h}$ by using ball mill, and cold isostatic pressed (CIPed) at $392 \mathrm{MPa}$ before pressure sintering. It was pressure-sintered in $1 \mathrm{MPa}-\mathrm{N}_{2}$ atmosphere at $2000^{\circ} \mathrm{C}$ for $4 \mathrm{~h}$ in graphite resistance furnace (FVPHP-R-10, FRET-40, Fujidempa Kogyo Co., Ltd.). The specimens with dimensions of $3 \times 4 \times 37 \mathrm{~mm}$ were cut and ground $\left(R_{\mathrm{a}}:<0.2 \mu \mathrm{m}\right)$, and their edges were chamfered at $45^{\circ}$.

The coated specimens were prepared by the reaction sintering method after dip-coating. The slurry for dip-coating was composed of $\mathrm{Lu}_{2} \mathrm{O}_{3}$ and $\mathrm{SiO}_{2}$ powder with dispersant (A-6114, Toagosei Co., Ltd.), polyvinyl alcohol aqueous solution (163-03045, Wako Pure Chemical Industries, Ltd.; about 500 average polymerization degrees), deformer (RA20A, Matsumoto Yushi-Seiyaku Co., Ltd.), and distilled water. The detailed composition is summarized in Table 1. It was ball-milled for $48 \mathrm{~h}$. The composition of $\mathrm{SiO}_{2} / \mathrm{Lu}_{2} \mathrm{O}_{3}$ in the slurry for the 1 st coating was 1.0 (molar ratio), which was less than the stoichiometric composition of $\mathrm{Lu}_{2} \mathrm{Si}_{2} \mathrm{O}_{7}\left(\mathrm{SiO}_{2} /\right.$ $\mathrm{Lu}_{2} \mathrm{O}_{3}=2.0$ ), because $\mathrm{SiO}_{2}$ was generated by oxidation of $\mathrm{Si}_{3} \mathrm{~N}_{4}$ in the sintering process of the coating layer. The specimens dipped in the slurry were CIPed at $392 \mathrm{MPa}$ before reaction sintering. This CIP treatment was performed in order to densify the $\mathrm{Lu}_{2} \mathrm{Si}_{2} \mathrm{O}_{7}$ coating layer by increasing the initial density before sintering. Reaction sintering was conducted in air at $1550^{\circ} \mathrm{C}$ for $20 \mathrm{~h}$. The heating rate was $2.6^{\circ} \mathrm{C} / \mathrm{min}$, and the cooling rate was $3.1^{\circ} \mathrm{C} / \mathrm{min}$ down to $1000^{\circ} \mathrm{C}$ followed by natural cooling. Triple- and 5 -times-coated specimens were also prepared by repeating the above-mentioned method 3 times and 5 times, respectively. (In the 2 nd -5 th coating, the composition of $\mathrm{SiO}_{2} / \mathrm{Lu}_{2} \mathrm{O}_{3}$ in the slurry was 2.0 (molar ratio), because the formation of $\mathrm{SiO}_{2}$ during the sintering was suppressed by the 1st coating layer.)

2.2 Evaluation of the coated $\mathrm{Si}_{3} \mathrm{~N}_{4}$

To obtain apparent activation energies for oxidation, the coated and uncoated specimens were exposed to air at 1300 , $1350,1400,1450$, and $1500^{\circ} \mathrm{C}$ for up to $100 \mathrm{~h}$. Long-term cycling oxidation tests were conducted at $1500^{\circ} \mathrm{C}$ in a static air atmosphere. It took $100 \mathrm{~h}$ for each cycle, and 10 cycles were carried out (total oxidation time was $1000 \mathrm{~h}$ ). All the specimens were set on the triangular poles of $\mathrm{Si}_{3} \mathrm{~N}_{4}$ (same as the uncoated specimen) during the oxidation test, in order to
Table 1. Composition of the Slurry for Coating

\begin{tabular}{lc}
\hline \multicolumn{1}{c}{ Composition } & mass $\%$ \\
\hline \hline $\mathrm{Lu}_{2} \mathrm{O}_{3}$ and $\mathrm{SiO}_{2}$ powder & 59.6 \\
\hline PVA 5mass $\%$ aqueous solution & 11.9 \\
\hline Dispersant & 3.0 \\
\hline Deformer & 0.6 \\
\hline Distilled water & 24.9 \\
\hline
\end{tabular}

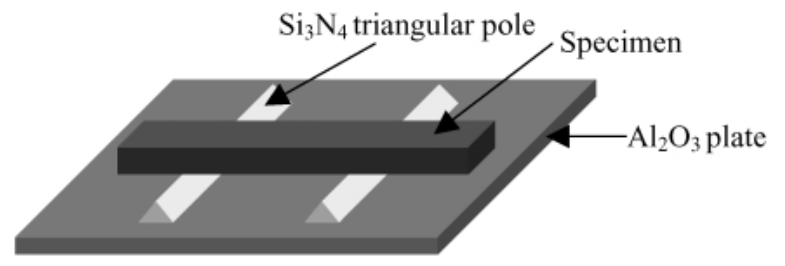

Fig. 1. Schematic of the specimen setting in the furnace.

prevent the direct diffusion of impurities such as $\mathrm{Na}$ from $\mathrm{Al}_{2} \mathrm{O}_{3}$ plate to specimens. Schematic of the specimen setting in the furnace was shown in Fig. 1. Before and after the cycling oxidation at $1500^{\circ} \mathrm{C}$ for 100,500 , and $1000 \mathrm{~h}$, the four-point bending tests (inner and outer spans were $10 \mathrm{~mm}$ and $30 \mathrm{~mm}$, respectively) were conducted at room temperature at a crosshead speed of $0.5 \mathrm{~mm} / \mathrm{min}$ (Sintech $10 / \mathrm{GL}$, MTS Systems Corp., U.S.A.). High-temperature flexural strength before oxidation was also measured at $1200,1300,1400$, and $1500^{\circ} \mathrm{C}$ in air using a system (Model 1186 and 4500, Instron Corp., U.S.A.). Four specimens were used for the measurements. The microstructures and compositions were examined by scanning electron microscopy (SEM; JSM-5600 and JSM6330F, JEOL) and energy dispersive spectroscopy (EDS; JED-2140, JEOL), respectively. Crystalline phases were identified by X-ray diffractometry (XRD; RINT 2000, Rigaku Corp.), using $\mathrm{Cu} \mathrm{K} \alpha$ radiation at $40 \mathrm{kV}$ and $100 \mathrm{~mA}$. The surface roughness of the specimens was defined by arithmetic mean roughness value $\left(R_{\mathrm{a}}\right)$ using a test machine (SV-624.3D, Mitutoyo Corp.).

\section{Results and discussion}

\subsection{Characterization of the coated $\mathrm{Si}_{3} \mathrm{~N}_{4}$}

The density of the uncoated $\mathrm{Si}_{3} \mathrm{~N}_{4}$ specimen was 3.35-3.37 $\mathrm{g} / \mathrm{cm}^{3}$, and almost $100 \%$ of the theoretical density. Figure 2 shows the XRD pattern. The $\beta-\mathrm{Si}_{3} \mathrm{~N}_{4}$ phase with $\mathrm{Lu}_{2} \mathrm{Si}_{2} \mathrm{O}_{7}$ in the grain boundary regions was observed. $\mathrm{The} \mathrm{Lu}_{2} \mathrm{Si}_{2} \mathrm{O}_{7}$ phase in the grain boundary regions was the same with that of coating layer, leading to the chemical compatibility between the layer and $\mathrm{Si}_{3} \mathrm{~N}_{4}$ substrate.

Using the reaction sintering method after dip-coating, $\mathrm{Si}_{3} \mathrm{~N}_{4}$ was coated with $\mathrm{Lu}_{2} \mathrm{Si}_{2} \mathrm{O}_{7}$ layer through the intermediate $\mathrm{SiO}_{2}$ rich phase. Figure 3 shows SEM micrographs of surface and cross section of the coated specimens (Fig. 3(3) for the singlecoated one, and Figs. 3(1), (2), and (4) for the triple-coated one). The composition and crystalline phases of the coating layer were characterized by EDS (Fig. 4) and XRD (Fig. 5) analyses, respectively. From these analyses, it was found that $\mathrm{Lu}_{2} \mathrm{Si}_{2} \mathrm{O}_{7}$ layer was coated on the $\mathrm{Si}_{3} \mathrm{~N}_{4}$ substrate through the intermediate $\mathrm{SiO}_{2}$-rich phase. The layer was relatively dense 


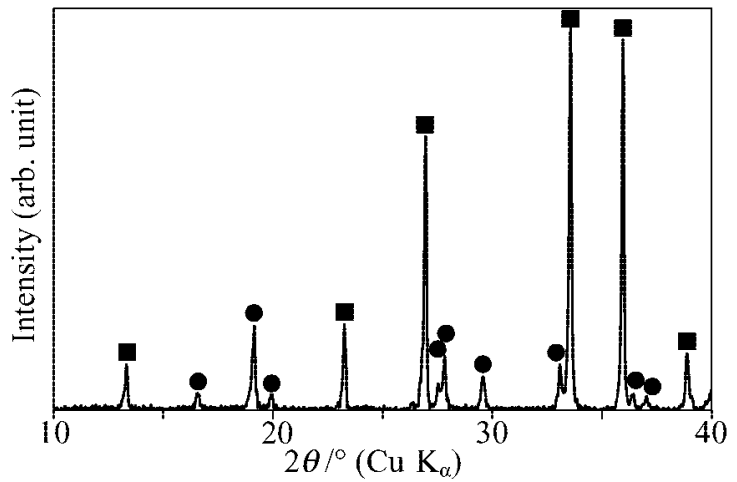

Fig. 2. XRD pattern of the uncoated $\mathrm{Si}_{3} \mathrm{~N}_{4}\left(\square-\mathrm{Si}_{3} \mathrm{~N}_{4}(33-1160)\right.$, $\left.\mathrm{Lu}_{2} \mathrm{Si}_{2} \mathrm{O}_{7}(34-0509)\right)$.
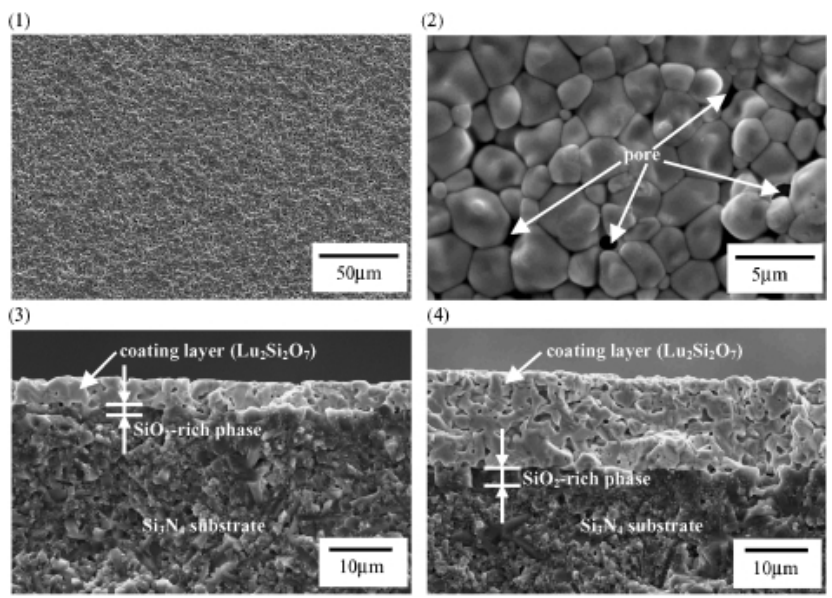

Fig. 3. SEM micrographs of the coated $\mathrm{Si}_{3} \mathrm{~N}_{4}$ ((1) surface of the triple-coated one, (2) magnified surface of the triple-coated one, (3) cross section of the single-coated one, (4) cross section of the triple-coated one).

(1)

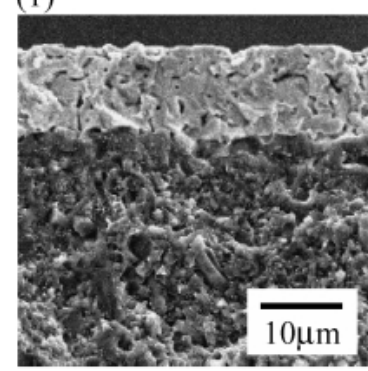

(2)

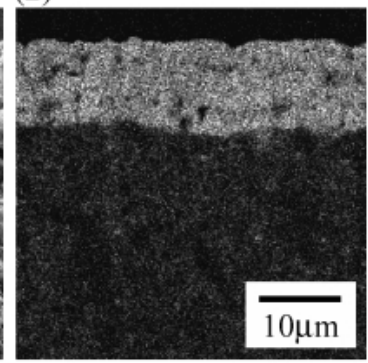

with several pores, and strongly jointed to the substrate. The amorphous and crystalline (cristobalite) $\mathrm{SiO}_{2}$-rich phase was formed by the oxidation of the substrate through several pores in the $\mathrm{Lu}_{2} \mathrm{Si}_{2} \mathrm{O}_{7}$ layer during the sintering process. The $\mathrm{SiO}_{2}$ rich phase increased with increasing thickness of the coating layer. It was because the total sintering time of the coating layer was longer in the specimen with thicker layer, to progress further oxidation of $\mathrm{Si}_{3} \mathrm{~N}_{4}$. Table 2 shows the thickness of the layer, average grain size in the layer, aspect ratio, and surface roughness $\left(R_{\mathrm{a}}\right)$ of each of the coated specimens (with data after long-term cycling oxidation at $1500^{\circ} \mathrm{C}$ for $1000 \mathrm{~h}$ in air). The thickness of the layer was $3-6 \mu \mathrm{m}$ for the single-coated specimen, $12-16 \mu \mathrm{m}$ for the triple-coated one, and 26-29 $\mu \mathrm{m}$ for the 5-times-coated one, respectively. It indicates that simply repeating coating process could control the thickness of the layer. The average grain sizes in the layer were 2.10-2.76 $\mu \mathrm{m}$, and average aspect ratios were 1.51-1.59. There was no distinct difference in the grain size and aspect ratio among all the coated specimens. $R_{\mathrm{a}}$ of the coated ones before oxidation was relatively small $(0.20-0.24 \mu \mathrm{m})$, indicating that the coating layer was very homogeneous although the coating method

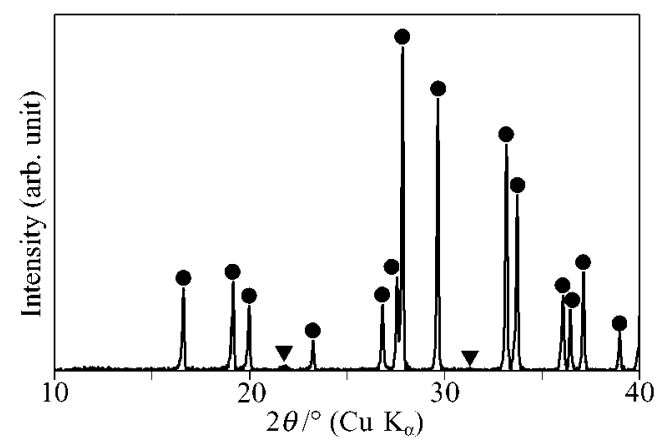

Fig. 5. XRD pattern of the triple-coated $\mathrm{Si}_{3} \mathrm{~N}_{4}$ 0509), $\nabla \mathrm{SiO}_{2}$ (cristobalite: $\left.39-1425\right)$ ).

Fig. 4. SEM-EDS analyses of the coating layer ((1) SEM micrograph of the cross section of the triple-coated $\mathrm{Si}_{3} \mathrm{~N}_{4}$. Element mapping of (2) $\mathrm{Lu},(3) \mathrm{Si}$, and (4) $\mathrm{O}$, indicated by white color).

Table 2. Thickness of the Coating Layer, Average Grain Size in the Layer Aspect Ratio, and Surface Roughness $\left(R_{\mathrm{a}}\right)$ of Each of the Single-, Triple-, and 5-Times-Coated $\mathrm{Si}_{3} \mathrm{~N}_{4}$ Before and After Long-Term Cycling Oxidation Test at $1500^{\circ} \mathrm{C}$ for $1000 \mathrm{~h}$ in Air

\begin{tabular}{ccccccccc}
\hline & \multicolumn{2}{c}{ Thickness $/ \mu \mathrm{m}$} & \multicolumn{2}{c}{ Average grain size $/ \mu \mathrm{m}$} & \multicolumn{2}{c}{ Average aspect ratio } & \multicolumn{2}{c}{ Roughness: $R_{\mathrm{a}} / \mu \mathrm{m}$} \\
\cline { 2 - 9 } & before & after & before & after & before & after & before & after \\
\hline Single-coated & $3-6$ & $2-4$ & $2.76 \pm 1.26$ & $4.69 \pm 2.10$ & $1.52 \pm 0.49$ & $1.53 \pm 0.38$ & $0.22 \pm 0.03$ & $1.43 \pm 0.40$ \\
\hline Triple-coated & $12-16$ & $10-14$ & $2.10 \pm 0.95$ & $7.12 \pm 3.00$ & $1.51 \pm 0.47$ & $1.55 \pm 0.47$ & $0.24 \pm 0.03$ & $0.88 \pm 0.29$ \\
\hline 5-times-coated & $26-29$ & $23-29$ & $2.31 \pm 1.01$ & $8.69 \pm 4.41$ & $1.59 \pm 0.50$ & $1.56 \pm 0.42$ & $0.20 \pm 0.04$ & $0.47 \pm 0.08$ \\
\hline
\end{tabular}


was quite simple.

3.2 Oxidation resistance

In general, when $\mathrm{Si}_{3} \mathrm{~N}_{4}$ is oxidized, $\mathrm{SiO}_{2}$ scale is generated by the following Reaction (1).

$$
\mathrm{Si}_{3} \mathrm{~N}_{4}(s)+3 \mathrm{O}_{2}(g)=3 \mathrm{SiO}_{2}(s)+2 \mathrm{~N}_{2}(g)
$$

In the case of the oxidation of $\mathrm{Si}_{3} \mathrm{~N}_{4}$ with additives, silicate phases are also generated by the migration of additive cations from the grain boundary regions to the surface. Therefore, oxygen or cation diffusion is rate controlling in oxidation of $\mathrm{Si}_{3} \mathrm{~N}_{4}$, and oxidation behavior obeys a parabolic law as follows:

$$
\Delta m^{2}=k_{\mathrm{p}} t
$$

where $\Delta m$ is the weight gain per unit surface area, $k_{\mathrm{p}}$ is the parabolic oxidation rate constant, and $t$ is the oxidation time. The oxidation rate constant at each temperature of 1300 to $1500^{\circ} \mathrm{C}$ was examined to obtain Arrhenius plots, as shown in Fig. 6. The calculated apparent activation energy was 310.3 $\mathrm{kJ} / \mathrm{mol}, 455.6 \mathrm{~kJ} / \mathrm{mol}$, and $523.1 \mathrm{~kJ} / \mathrm{mol}$ for the uncoated, single-coated, and triple-coated specimens, respectively. They increased with increasing the thickness of the coating layer.

Long-term cycling oxidation behaviors were investigated at $1500^{\circ} \mathrm{C}$ for up to $1000 \mathrm{~h}$ in air for the uncoated, single-coated, triple-coated, and 5-times-coated specimens. The weight gains were described as a function of square root of time, as shown in Fig. 7. The plot of the uncoated specimen showed linearity, indicating that oxidation behavior obeyed a parabolic law (Eq. (2)). However, in the case of the coated ones, small deviations from linearity were observed. The deviations were

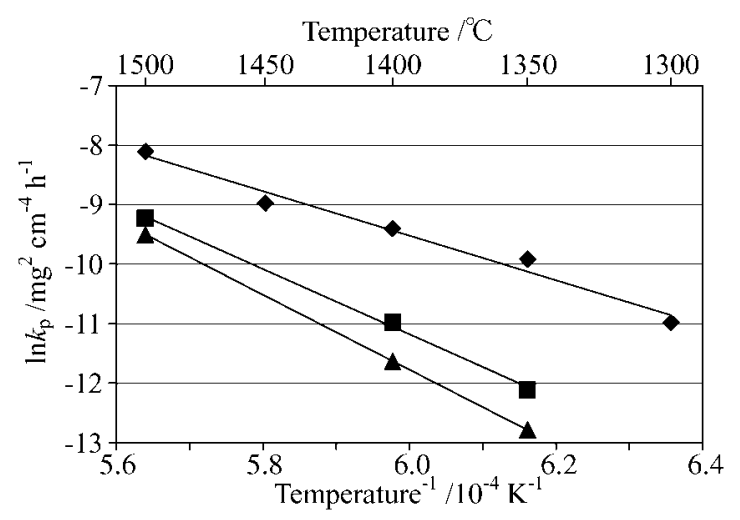

Fig. 6. Arrhenius plots of the uncoated $(>)$, single-coated and triple-coated $(\boldsymbol{\Delta}) \mathrm{Si}_{3} \mathrm{~N}_{4}$ at $1300-1500^{\circ} \mathrm{C}$ in air. attributed mainly to the diffusion of $\mathrm{SiO}_{2}$ phase to the measured specimens from the triangular pole of $\mathrm{Si}_{3} \mathrm{~N}_{4}$ during oxidation, which was used for setting the specimens. In fact, the area of the coated specimens contacted with the triangular pole contained more $\mathrm{SiO}_{2}$ phase than the un-contacted area. The total weight gain was $0.336 \mathrm{mg} / \mathrm{cm}^{2}, 0.248 \mathrm{mg} / \mathrm{cm}^{2}$, and $0.225 \mathrm{mg} / \mathrm{cm}^{2}$ for single-coated, triple-coated and 5-timescoated specimens, respectively; they were all less than that of the uncoated one, $0.444 \mathrm{mg} / \mathrm{cm}^{2}$. It decreased with increasing the thickness of the coating layer and underlying $\mathrm{SiO}_{2}$-rich phase. However, the difference of weight gains between tripleand 5-times-coated specimens was small. The total weight gain decreased by up to $51 \%$, indicating that oxidation resistance improved by about $100 \%$. The improvement was attributed to the protection of the substrate from an oxidative environment by the $\mathrm{Lu}_{2} \mathrm{Si}_{2} \mathrm{O}_{7}$ layer and underlying $\mathrm{SiO}_{2}$-rich phase.

Figure 8 shows XRD patterns of the surface of the uncoated and triple-coated specimens after the oxidation at $1500^{\circ} \mathrm{C}$ for $1000 \mathrm{~h}$ in air. In the case of the uncoated specimen, large amount of $\mathrm{SiO}_{2}$ (cristobalite) phase was generated and $\mathrm{Lu}_{2} \mathrm{Si}_{2} \mathrm{O}_{7}$ phase increased remarkably after the oxidation. The cristobalite phase was formed by the oxidation of $\mathrm{Si}_{3} \mathrm{~N}_{4}$, and $\mathrm{Lu}_{2} \mathrm{Si}_{2} \mathrm{O}_{7}$ phase was formed by reaction between $\mathrm{SiO}_{2}$ and remaining $\mathrm{Lu}_{2} \mathrm{O}_{3}$ or related elements in grain boundary regions of $\mathrm{Si}_{3} \mathrm{~N}_{4}$. The XRD pattern of $\mathrm{Lu}_{2} \mathrm{Si}_{2} \mathrm{O}_{7}$ phase in the uncoated specimen showed strong preferred orientation of $(h k 0)$ plane. The peaks related to (110) and (220) planes drastically increased after the oxidation. It indicates that

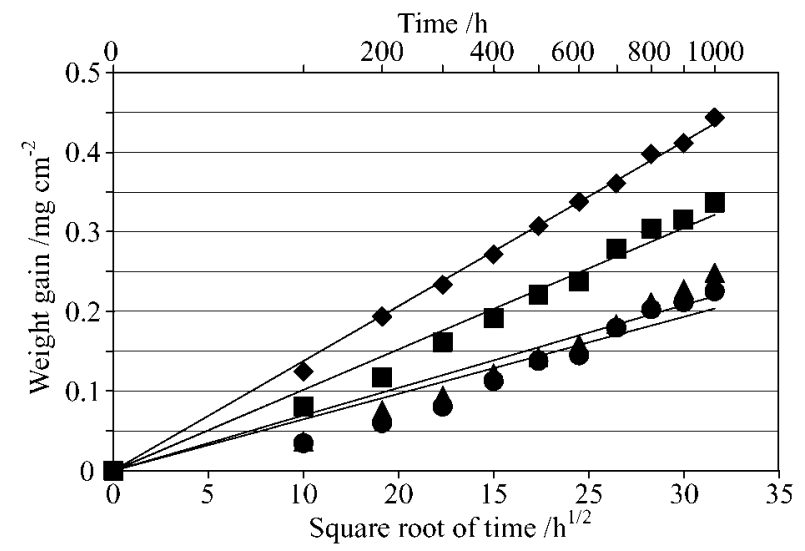

Fig. 7. Long-term oxidation behaviors of the uncoated $(\checkmark)$, singlecoated $(\square)$, triple-coated $(\boldsymbol{\Delta})$, 5-times-coated $(\mathbf{O}) \mathrm{Si}_{3} \mathrm{~N}_{4}$ at $1500^{\circ} \mathrm{C}$ for up to $1000 \mathrm{~h}$ in air.
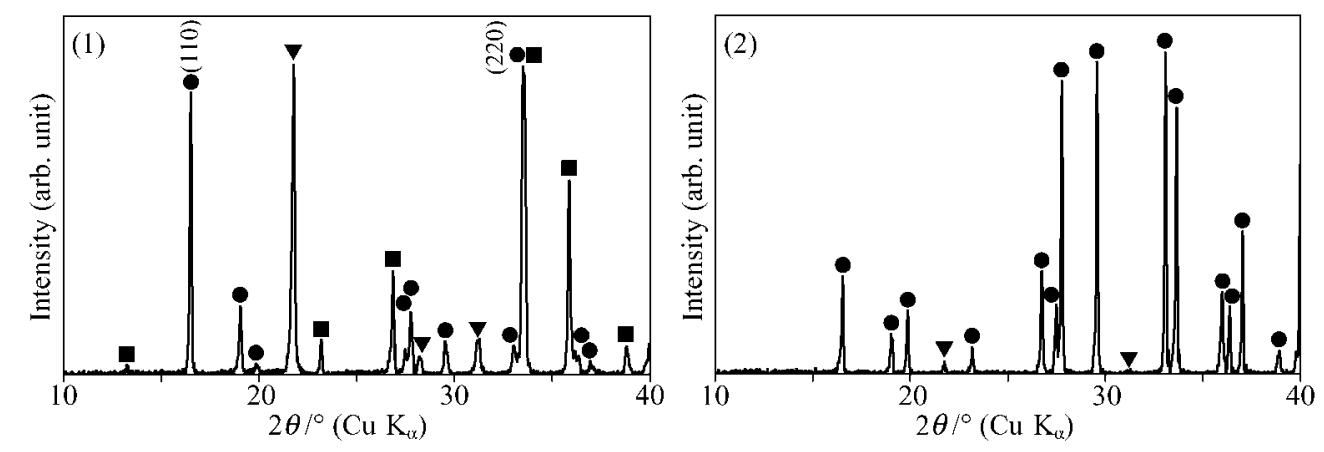

Fig. 8. XRD patterns of the uncoated (1) and triple-coated (2) $\mathrm{Si}_{3} \mathrm{~N}_{4}$ after long-term oxidation at $1500^{\circ} \mathrm{C}$ for $1000 \mathrm{~h}$ in air (33-1160), $\mathrm{Lu}_{2} \mathrm{Si}_{2} \mathrm{O}_{7}(34-0509), \nabla \mathrm{SiO}_{2}$ (cristobalite: 39-1425)). 

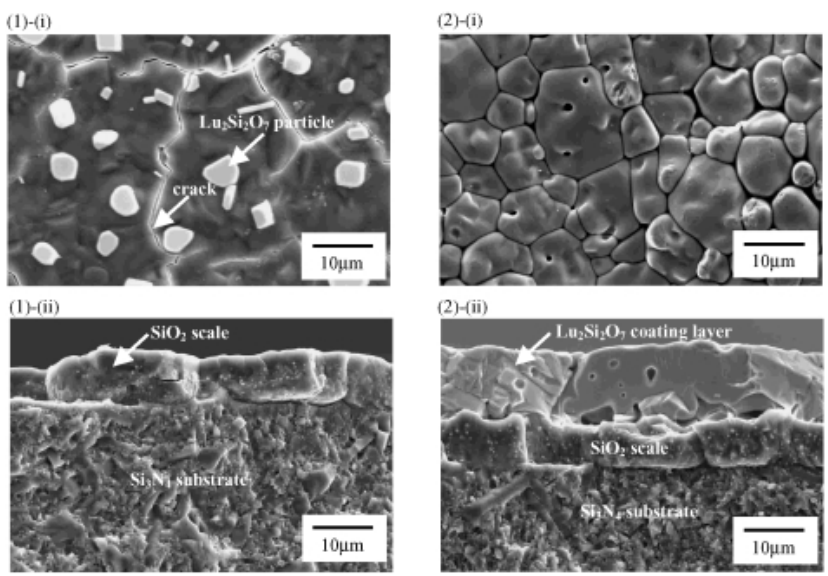

Fig. 9. SEM micrographs of the surface (i) and cross section (ii) of the uncoated (1) and triple-coated (2) $\mathrm{Si}_{3} \mathrm{~N}_{4}$ after long-term oxidation at $1500^{\circ} \mathrm{C}$ for up to $1000 \mathrm{~h}$ in air.

$\mathrm{Lu}_{2} \mathrm{Si}_{2} \mathrm{O}_{7}$ was crystallized anisotropically during the oxidation. Such anisotropic crystallization of oxidation product was also observed in the case of $\mathrm{RE}_{2} \mathrm{Si}_{2} \mathrm{O}_{7}$ by other researchers. ${ }^{14), 19)}$ In the case of the triple-coated specimen, the cristobalite phase also increased a little. It indicates that $\mathrm{Si}_{3} \mathrm{~N}_{4}$ was somewhat oxidized to form cristobalite, and/or that the pre-existed $\mathrm{SiO}_{2}$ rich phase was further crystallized to generate large amount of cristobalite with small amount of amorphous $\mathrm{SiO}_{2}$. The $\mathrm{Lu}_{2} \mathrm{Si}_{2} \mathrm{O}_{7}$ phase in the coating layer was maintained without phase transition.

Figure 9 shows SEM micrographs of the surface and cross section of the uncoated and coated specimens after the oxidation at $1500^{\circ} \mathrm{C}$ for $1000 \mathrm{~h}$ in air. In the case of the uncoated one, $\mathrm{SiO}_{2}$ scale with a thickness of 6-10 $\mu$ m was generated with $\mathrm{Lu}_{2} \mathrm{Si}_{2} \mathrm{O}_{7}$ particles. The surface was drastically cracked, because of the large mismatch of thermal expansion coefficients between $\mathrm{SiO}_{2}$ scale and $\mathrm{Si}_{3} \mathrm{~N}_{4}$ substrate. In the case of the triple-coated one, $\mathrm{Lu}_{2} \mathrm{Si}_{2} \mathrm{O}_{7}$ layer did not completely protect the substrate. $\mathrm{SiO}_{2}$ scale also existed between the layer and substrate, and some cracks were observed in the scale. It was due to the oxidation of the substrate, and due to the further crystallization of the pre-existed intermediate $\mathrm{SiO}_{2}$-rich phase (amorphous and crystalline $\mathrm{SiO}_{2}$ phase before the oxidation). The oxidation presumably occurred through several pores of the $\mathrm{Lu}_{2} \mathrm{Si}_{2} \mathrm{O}_{7}$ layer, which permitted oxygen to approach the substrate and intermediate $\mathrm{SiO}_{2}$-rich phase, and in fact small weight gains of the coated specimens occurred. The $\mathrm{SiO}_{2}$ scale beneath the $\mathrm{Lu}_{2} \mathrm{Si}_{2} \mathrm{O}_{7}$ layer in the coated specimens influenced the surface roughness. Figure 10 shows the surface roughness $\left(R_{\mathrm{a}}\right)$ of the specimens as a function of oxidation time. $R_{\mathrm{a}}$ increased with increasing the oxidation time. It also increased with decreasing the thickness of the coating layer, probably because the $\mathrm{SiO}_{2}$ scale lifted the thinner layer up relatively easily when the scale increased between the layer and substrate. However, it should be noted that no delamination was observed in all the coated specimens even after the oxidation. It indicates that the coating layer with $\mathrm{SiO}_{2}$ scale was strongly jointed to the substrate. The thickness of the coating layer after the oxidation became smaller than that before (Figs. 3, 9 and Table 2), indicating further densification of the layer progressed. This densification also progressed with grain growth. Figure 11 shows the average grain size of the coating layer and aspect ratio as a function of oxidation time. The grain size increased with increasing oxidation time and

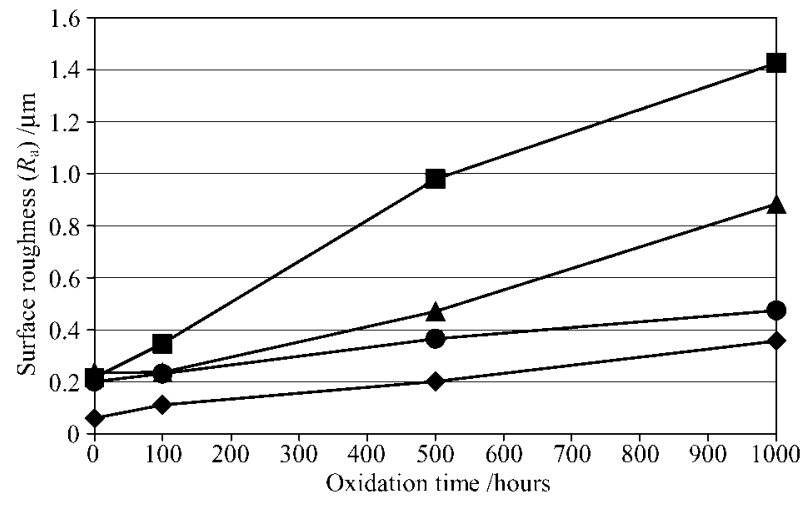

Fig. 10. Surface roughness of the uncoated $(>)$, single-coated ), triple-coated $(\boldsymbol{\Delta})$, 5-times-coated $(\mathbf{O}) \mathrm{Si}_{3} \mathrm{~N}_{4}$ as a function of oxidation time at $1500^{\circ} \mathrm{C}$ in air.

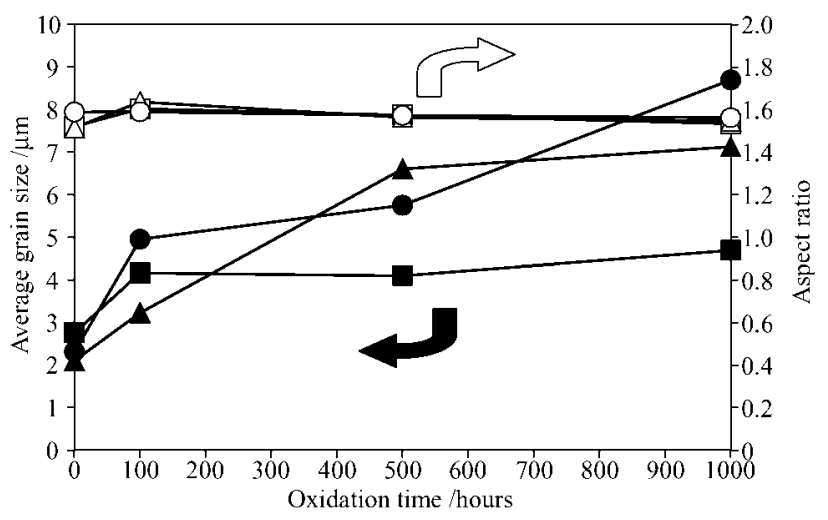

Fig. 11. Average grain size and aspect ratio in each coating layer of single-coated $(\square, \square)$, triple-coated $(\boldsymbol{\Lambda}, \triangle)$, 5-times-coated $(\mathbf{O}, \bigcirc)$ $\mathrm{Si}_{3} \mathrm{~N}_{4}$ as a function of oxidation time at $1500^{\circ} \mathrm{C}$ in air. Black colored marker indicates average grain size and white colored one indicates aspect ratio.

increasing the thickness of the coating layer. It indicates that grains in the thicker layers have less constraint from the substrate than those in the thinner ones, leading to the further progress of grain growth. The aspect ratio was maintained during the oxidation in all the coated specimens.

The densification of the coating layer with grain growth means that the fabricated layer was not perfectly dense but had several pores. $\mathrm{Lu}_{2} \mathrm{Si}_{2} \mathrm{O}_{7}$ layer would be densified by longer oxidation time at higher temperatures (although the substrate would be also oxidized to form more $\mathrm{SiO}_{2}$ phase in this case) and by making more $\mathrm{SiO}_{2}$-rich composition of the slurry for coating (the accelerated densification would occur through the liquid phase sintering of $\mathrm{SiO}_{2}-\mathrm{Lu}_{2} \mathrm{O}_{3}$ system in this case). However, the excessive $\mathrm{SiO}_{2}$ phase would cause the delamination of the coating layer through the volatilization of $\mathrm{SiO}_{2}$ in more severe corrosive environment containing water vapor. ${ }^{22), 23)}$ Therefore, it is necessary to further develop a coating layer, which is perfectly dense with neither pores nor $\mathrm{SiO}_{2}$ phase.

\subsection{Strength retention after oxidation}

Figure 12 shows the flexural strengths of the uncoated, and coated specimens at room temperature before and after longterm cycling oxidation at $1500^{\circ} \mathrm{C}$ for up to $1000 \mathrm{~h}$ in air. Before the oxidation, the strength of the uncoated specimen was smaller $(\sim 470 \mathrm{MPa})$ than that of commercial $\mathrm{Si}_{3} \mathrm{~N}_{4}$ 


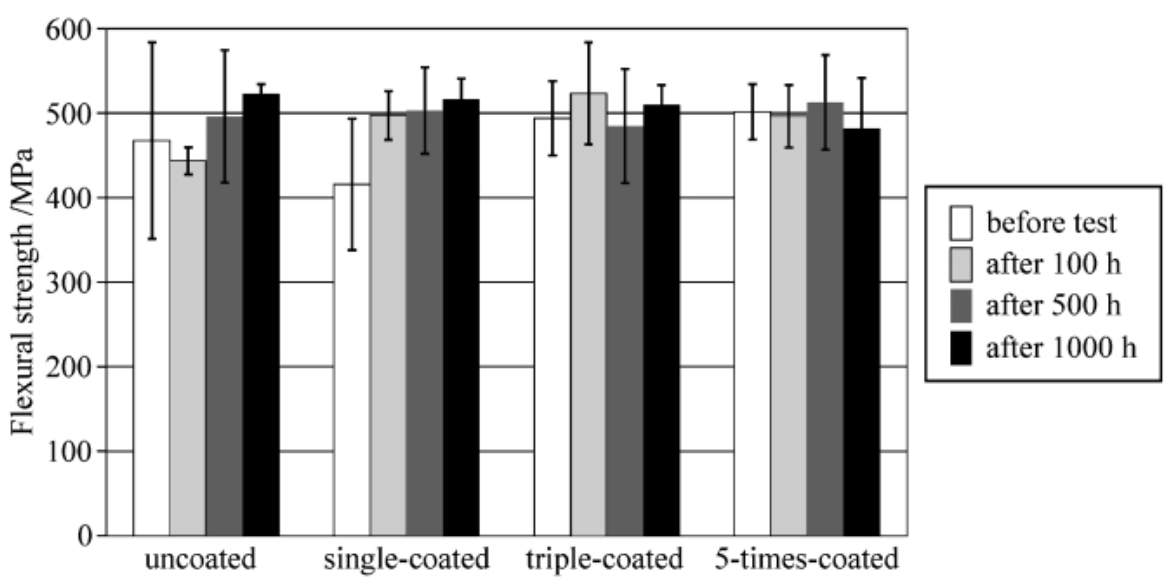

Fig. 12. Flexural strengths of the uncoated, single-coated, triple-coated, 5-times-coated $\mathrm{Si}_{3} \mathrm{~N}_{4}$ before and after long-term oxidation at $1500^{\circ} \mathrm{C}$ for up to $1000 \mathrm{~h}$ in air. Error bars stand for \pm 1 standard deviations.

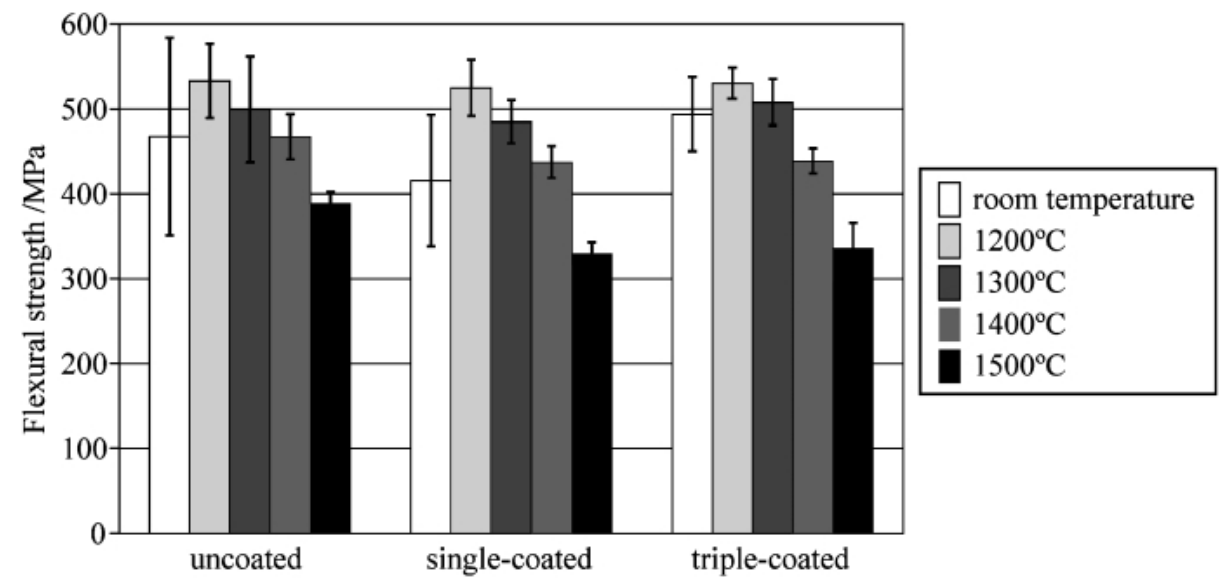

Fig. 13. Retentions of flexural strengths of the uncoated, single-coated, triple-coated $\mathrm{Si}_{3} \mathrm{~N}_{4}$ from room temperature to $1500^{\circ} \mathrm{C}$ in air. Error bars stand for \pm 1 standard deviations.

perhaps due to the grain growth. The strengths of the coated specimens, except that of the single-coated one, were a little higher than that of the uncoated one before the oxidation. It was attributed mainly to the healing of defects inside and on the substrate by heat treatment during the sintering process of the coating layer. This healing phenomenon in $\mathrm{Si}_{3} \mathrm{~N}_{4}$ ceramics was observed by other researchers. ${ }^{24)}$ After the oxidation, the strengths of the triple-coated and 5-times-coated specimens were maintained, while the uncoated and single-coated ones showed the strength increase. The strength increase of the uncoated one after the oxidation was presumably due to oxidation-induced strengthening effects including healing of defects as well as compressive stress by the formed $\mathrm{SiO}_{2}$ scale. ${ }^{24)}$,25) This result, however, was different from the results by other researchers, ${ }^{15), 16)}$ where the damage of the substrate beneath the scale with several pores degraded the strength. The observed strength increase after the oxidation was probably because the effect of the damage of substrate was less than the effect of the oxidation-induced strengthening in the range of relatively low strength $(400-600 \mathrm{MPa})$.

3.4 Strength retention at high temperatures

The high-temperature bending tests of the uncoated and coated specimens were conducted at $1200-1500^{\circ} \mathrm{C}$ in air, and the strength retentions were examined, as shown in Fig. 13.
The strengths at 1200 and $1300^{\circ} \mathrm{C}$ were all higher than those at room temperature with small standard deviations. It was attributed to the healing effect inside and on the substrate. The uncoated specimen showed very good strength retention at high temperatures, which was attributed to the formation of $\mathrm{Lu}_{2} \mathrm{Si}_{2} \mathrm{O}_{7}$ in the grain boundary regions with high melting point and to its crystallization during the sintering process of $\mathrm{Si}_{3} \mathrm{~N}_{4}$ (Fig. 2). In addition, $\mathrm{Lu}^{3+}$ has a small ionic radius, and produces a stronger grain boundary phase. ${ }^{3)}$ The single-coated and triple-coated specimens also showed good high-temperature strength; however, the strength retentions at $1400-1500^{\circ} \mathrm{C}$ were not as good as that of the uncoated specimen. This was presumably because the coated specimens contained amorphous $\mathrm{SiO}_{2}$ phase in the intermediate $\mathrm{SiO}_{2}$-rich phase (between the $\mathrm{Lu}_{2} \mathrm{Si}_{2} \mathrm{O}_{7}$ layer and substrate) and inside the substrate, which was softened at $1400-1500^{\circ} \mathrm{C}$. This speculation was supported by the fractured surface observations (Fig. 14). The fractured surface of the coated specimen was macroscopically flatter than that of the uncoated one. Therefore, it is very important to fabricate the coating layer without $\mathrm{SiO}_{2}$ phase for high-temperature strength retention as well as for high oxidation resistance in severe environment. 
(1)

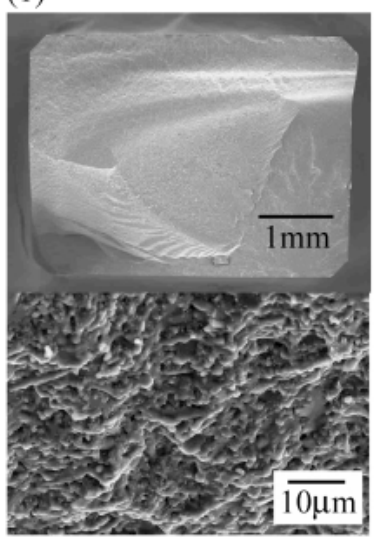

(2)

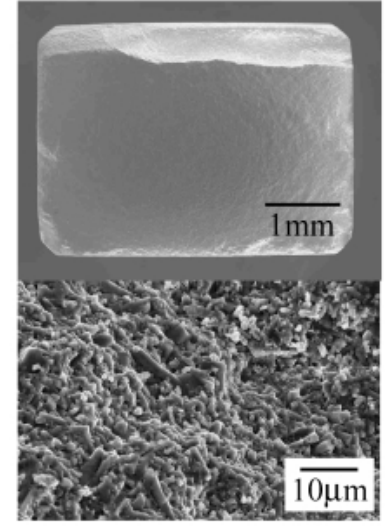

Fig. 14. Typical fractured surfaces of the uncoated (1) and triplecoated (2) $\mathrm{Si}_{3} \mathrm{~N}_{4}$ at $1500^{\circ} \mathrm{C}$ in air.

\section{Conclusions}

$\mathrm{Si}_{3} \mathrm{~N}_{4}$ coated with $\mathrm{Lu}_{2} \mathrm{Si}_{2} \mathrm{O}_{7}$ layer through the intermediate $\mathrm{SiO}_{2}$-rich phase was successfully fabricated by reaction sintering after dip-coating. The layer with a thickness of 3-29 $\mu \mathrm{m}$ was relatively dense with several pores and strongly jointed to the substrate through the intermediate phase. Simply repeating the coating process could control the thickness of the layer. The surface roughness was relatively small $(0.20-0.24$ $\mu \mathrm{m})$, indicating that the coating layer was very homogeneous although the coating method was quite simple.

The apparent activation energy of the coated $\mathrm{Si}_{3} \mathrm{~N}_{4}(523.1$ $\mathrm{kJ} / \mathrm{mol}$ ) for oxidation at $1300-1500^{\circ} \mathrm{C}$ in air was up to about 1.7 times higher than that of the uncoated one $(310.3 \mathrm{~kJ} /$ mol). After long-term cycling oxidation at $1500^{\circ} \mathrm{C}$ for up to $1000 \mathrm{~h}$ in air, the oxidation resistance was improved up to about $100 \%$ by increasing the thickness of coating layer. The improvement was attributed to the protection of the substrate from an oxidative environment by $\mathrm{Lu}_{2} \mathrm{Si}_{2} \mathrm{O}_{7}$ layer and underlying $\mathrm{SiO}_{2}$-rich phase.

Flexural strength of the coated $\mathrm{Si}_{3} \mathrm{~N}_{4}$ at room temperature was not deteriorated before and after the oxidation in comparison with that of the uncoated $\mathrm{Si}_{3} \mathrm{~N}_{4}$. However, the strength at 1400 and $1500^{\circ} \mathrm{C}$ in air was a little less than that of the uncoated $\mathrm{Si}_{3} \mathrm{~N}_{4}$. This deterioration was probably because the coated $\mathrm{Si}_{3} \mathrm{~N}_{4}$ contained amorphous $\mathrm{SiO}_{2}$ phase in the intermediate phase (between the $\mathrm{Lu}_{2} \mathrm{Si}_{2} \mathrm{O}_{7}$ layer and substrate) and inside the substrate, and it was softened at $1400-1500^{\circ} \mathrm{C}$.

The coating process used for the present research was simple, easy, and cost-effective. It was also applicable to complex-shaped components, and quite suitable for industrial applications. However, it is necessary to further develop a process in order to fabricate completely dense coating layer with neither pores nor $\mathrm{SiO}_{2}$ phase for higher oxidation and corrosion resistance as well as for higher strength retention at high temperatures.

Acknowledgements This work has been supported by the Ministry of Economy, Trade and Industry (METI) of Japan as part of the Synergy Ceramics Project. Part of the work has

been supported by the New Energy and Industrial Technology Development Organization (NEDO). The authors are members of the Joint Research Consortium of Synergy Ceramics. They wish to express their gratitude to Masahiro Asayama, Seiichi Suenaga and Takayuki Fukasawa of Toshiba Corp. and to Shunkichi Ueno of the National Institute of Advanced Industrial Science and Technology (AIST), for assistance received in the course of this work.

\section{References}

1) Tsuge, A. and Nishida, K., Am. Ceram. Soc. Bull., Vol. 57, pp. 424-426 (1978).

2) Komeya, K., Am. Ceram. Soc. Bull., Vol. 63, pp. 1158-1159 (1984).

3) Sanders, W. A. and Mieskowski, D. M., Am. Ceram. Soc. Bull., Vol. 64, pp. 304-309 (1985).

4) Knickerbocker, S. H., Zangvil, A. and Brown, S. D., J. Am. Ceram. Soc., Vol. 68, pp. C99-C101 (1985).

5) Cinibulk, M. K., Thomas, G. and Johnson, S. M., J. Am. Ceram. Soc., Vol. 75, pp. 2050-2055 (1992).

6) Anzai, K. and Hashimoto, H., J. Mater. Sci., Vol. 12, pp. 2351-2353 (1977).

7) Wiederhorn, S. M. and Ferber, M. K., Current Opinion in Solid State and Materials Science, Vol. 5, pp. 311-316 (2001).

8) Lofaj, F., Wiederhorn, S. M., Long, G. G., Hockey, B. J., Jemian, P. R., Browder, L., Andreason, J. and Taffner, U., J. Eur. Ceram. Soc., Vol. 22, pp. 2479-2487 (2002).

9) Guo, S., Hirosaki, N., Yamamoto, Y., Nishimura, T. and Mitomo, M., Scripta Materialia, Vol. 45, pp. 867-874 (2001).

10) Guo, S., Hirosaki, N., Yamamoto, Y., Nishimura, T. and Mitomo, M., J. Eur. Ceram. Soc., Vol. 23, pp. 537-545 (2003).

11) Hirosaki, N., Yamamoto, Y., Nishimura, T., Mitomo, M., Takahashi, J., Yamane, H. and Shimada, M., J. Am. Ceram. Soc., Vol. 85, pp. 2861-2863 (2002).

12) Mieskowski, D. M. and Sanders, W. A., J. Am. Ceram. Soc., Vol. 68, pp. C160-C163 (1985).

13) Park, H., Kim, H.-E. and Niihara, K., J. Am. Ceram. Soc., Vol. 80, pp. 750-756 (1997).

14) Cinibulk, M. K., Thomas, G. and Johnson, S. M., J. Am. Ceram. Soc., Vol. 75, pp. 2044-2049 (1992).

15) Guo, S., Hirosaki, N., Yamamoto, Y., Nishimura, T. and Mitomo, M., J. Am. Ceram. Soc., Vol. 85, pp. 1607-1609 (2002).

16) Klemm, H., Taut, C. and Wötting, G., J. Eur. Ceram. Soc., Vol. 23, pp. 619-627 (2003).

17) Choi, H.-J., Lee, J.-G. and Kim, Y.-W., J. Mater. Sci., Vol. 32, pp. 1937-1942 (1997).

18) Park, H., Kim, H.-W. and Kim, H.-E., J. Am. Ceram. Soc., Vol. 81, pp. 2130-2134 (1998).

19) Kim, H.-W., Koh, Y.-H. and Kim, H.-E., J. Mater. Res., Vol. 15, pp. 1478-1482 (2000).

20) Klemm, H. and Schubert, C., J. Am. Ceram. Soc., Vol. 84, pp. 2430-2432 (2001).

21) Suetsuna, T., Ishizaki, M., Ando, M., Kondo, N., Ohji, T. and Kanzaki, S., J. Ceram. Soc. Japan, Vol. 112, pp. 301-304 (2004).

22) Jacobson, N. S., Opila, E. J. and Lee, K. N., Current Opinion in Solid State and Materials Science, Vol. 5, pp. 301-309 (2001).

23) Klemm, H., J. Eur. Ceram. Soc., Vol. 22, pp. 2735-2740 (2002).

24) Choi, S. R. and Tikare, V., Scripta. Metall. Mater., Vol. 26, pp. 1263-1268 (1992).

25) Lange, F. F., J. Am. Ceram. Soc., Vol. 63, pp. 38-40 (1980). 